\title{
On the importance of the bullet jacket during the penetration process: reversed- ballistic experimental and numerical study
}

\author{
Denny Lesmana $^{12 *}$, Faizal Arifurrahman ${ }^{13}$, Amer Hameed $^{1}$, G. J. Appleby-Thomas ${ }^{1}$, Sigit P Santosa ${ }^{3}$ \\ ${ }^{1}$ Centre for Defence Engineering, Cranfield University, Defence Academy of the United Kingdom, Shrivenham, Swindon, SN6 8LA, UK \\ ${ }^{2}$ Munnition Division, PT Pindad Persero, Jl. Gatot Subroto, No 517 Bandung 40285, Indonesia \\ ${ }^{3}$ Lightweight Structures Research Group, Faculty of Mechanical and Aerospace Engineering, Institut Teknologi Bandung, Ganesha 10, \\ Bandung 40132, \\ Indonesia
}

\begin{abstract}
The behaviour of exposed and copper-jacketed $12.7 \mathrm{~mm}$ En8 steel cores impacting against 5 and 9 $\mathrm{mm}$ Armox Advance plates was investigated to determine the significance of the jacket during the penetration. The target plates were accelerated into stationary projectiles (a reversed-ballistic configuration) and the impact was monitored using a multi-channel flash X-ray system to gain insight into the interaction of the core target. Numerical simulations were also carried out to compare result with the experimental testing. Explicit numerical software LSDYNA was used to model the behaviour of the target and the projectile during the impact collision. Fragments of the core and target plate were collected post-shot for analysis. A similar penetration behaviour was observed for both plates, although the post-shot core was shorter after impacting against the $9 \mathrm{~mm}$ plate, consistent with enhanced erosion behaviour. The copper jacket protected the core, resulting in greater surface defeat and dwell compared to the unjacketed core. Numerical studies agreed on the cases of projectile impacting the $5 \mathrm{~mm}$ and $9 \mathrm{~mm}$ target. However, the target fracture cannot be captured. This could be caused by the input of material data and strain rate parameter modelling in LS-DYNA was limited, while the impact phenomenon was high velocity impact that the material exhibits a high-strain rate effect. Overall, the ductile jacket appeared to serve two functions: (1) absorbing reflected energy during impact, hence cushioning the impact and thereby preserving the core, and (2) constraining or confining the core. In this study, the steel core design and copper jacket has a more complex geometry compared to the simplified steel core designs often applied in several earlier ballistic studies. The captured flash X-rays revealed significantly less erosion in the jacketed cores, agreeing with the post-impact core length measurements.
\end{abstract}

Keywords: 12.7 mm armour piercing; high strain rate; reverse ballistic; gas guns; copper jacket; Armox Advance 



\section{Introduction}

The development of armour materials has great significance in enhancing the passive protection of combat vehicle as part of their design improvement. Substantial research has been reported to improve the ability of armour materials, such as ceramics; ultra-high hardness steel; aluminium alloys and polymers, to resist projectile penetration, involving both numerical simulations and empirical testing [1-4]. Other research has focused on the development of armour-piercing (AP) ammunition, particularly its ability to defeat hard materials such as steel and tungsten carbide [5,6]. AP ammunition improves the reliability of projectiles and outperforms standard ball rounds which consist of copper alloy jackets (described as copper jackets hereafter for simplicity) with a lead-antimony core. As lead-antimony is a soft material, only used to provide mass to bullet is given a ballistics shape using a copper jacket. In AP rounds, the lead-antimony core is replaced with steel or other material designed to defeat hardened targets. Therefore, a question arises on the viability of incorporating an expensive material in the manufacturing of AP ammunition.

Several studies have investigated the penetration and perforation mechanism of AP projectiles against armour materials. The copper jacket on a $7.62 \mathrm{~mm}$ projectile was recently shown to be important for the penetration or perforation of aluminum and silicon carbide armour [7]. A combination of numerical simulation and empirical experiments showed that the copper jacket tip pre-damaged the ceramic target prior to impact with the core. The presence of a jacket was shown to reduce the energy required by the core to indent and perforate the ceramic target, conferring a higher residual velocity because the core sustained less damage. Reverse ballistics testing, in which the target is accelerated towards a stationary projectile, was better for the observation of damage modes using flash X-ray images because material flow during the impact could be seen clearly due to the correlation between the projectile's position and the impactor 7 . Further studies of the copper jacket effect on projectiles have confirmed this behaviour, revealing that projectiles protected by a jacket consistently penetrate up to $10 \%$ deeper into steel targets compared to those without a jacket, but the underlying mechanism remains unclear [8]. The combination of a copper jacket and a cap covering the steel core achieved a small positive effect when aluminium targets were perforated using $7.62 \mathrm{~mm}$ APM2 bullets, with performance assessed by measuring the residual velocity $[9,10]$ The effect of the jacket has also been assessed during the penetration of ceramic armour by AK47 bullets, using ANSYS Autodyn $®$ simulations [11]. The authors found that the jacket significantly reduced the extent of radial deformation by the steel core, confining it and thus improving penetration. The projectile models for the simulations were prepared under four conditions: core only, jacketed core (full jacket), tip-only, and no-tip. This work has been used both to improve armour protection and to enhance the 
performance of AP ammunition. Other studies also observed projectiles performance in high-hardness and titanium based armours penetration by experimental and numerical simulation works [1215].

Here we used reverse ballistics combined with a four-channel flash X-ray system to investigate the penetration of Armox Advance steel plates. The AP steel core was quenched and tempered. The steel cores were mounted with and without copper jackets, providing further insight into the effect of the jacket during penetration and perforation. Both the steel core and copper jacket reported/used in this study has a comparatively complex design than the simplified steel cores often used in several previous studies. The design used in this study has a spear shape core to allow increased mass of the steel core as well as the penetration performance. Additionally, spear shape of the projectile improved its stability by reducing the distance between the centre of gravity (c.g) and the centre of pressure (c.p). In the configuration under consideration c.g moved forward towards the c.p. Further, wave propagation into the target as a function of projectile configuration was directly interrogated via a novel pressure gauge-based technique. This technique was introduced to observe copper jacket effect on high hardness steel penetration in high strain rate condition quantitatively.

\section{Experimental Setup}

\subsection{Materials}

The core and target materials employed in this reverse ballistics test were En8 and Armox Advance steel respectively, with stock (half-hard) copper for the jackets. Aluminium 7075 targets were used for the pressure gauge test. The key properties of these materials are summarised in Table 1.

As shown in Figure 1, the impactors consisted of acetal-saboted Armox Advance steel plates of either 5 or $9 \mathrm{~mm}$ thickness. The plates were fixed to the sabot using a slow-setting epoxy adhesive and were skimmed to ensure a finish perpendicular to the sabot outer edges. The $12.7 \mathrm{~mm}$ AP cores comprised En8 steel hardened at $860 \circ \mathrm{C}$ for 20 minutes before oil quenched, tempering at $250 \circ \mathrm{C}$ for 40 minutes and subsequent air cooling. The heat treatment produced the steel cores with a hardness of $558 \mathrm{HV}$ (Vickers hardness number, which $1 \mathrm{HV}$ is equal to $9.807 \mathrm{MPa}$ ). Two batches of hardened AP cores were assembled: one unjacketed and the other with a press-fitted copper jacket crimped in place by pressing copper jacket inside a die block with a modified punch. The punch was installed in a hydraulic pressing machine. The jacketed cores were polished to remove copper debris. 
Table 1. Material properties for reverse ballistic test [16-21].

\begin{tabular}{c|c|c|c|c}
\hline Material & $\begin{array}{c}\text { Measured } \\
\text { density } \\
\left(\mathbf{g} / \mathbf{c m}^{3}\right)^{\mathbf{a}}\end{array}$ & $\begin{array}{c}\text { Young's } \\
\text { modulus, } \\
\mathbf{E}(\mathbf{G P a})\end{array}$ & $\begin{array}{c}\text { Average } \\
\text { hardness } \\
\mathbf{( H V})^{\mathbf{c}}\end{array}$ & $\begin{array}{c}\text { Yield } \\
\text { strength, } \\
\sigma_{\mathbf{y}} \mathbf{( M P a )}\end{array}$ \\
\hline $\begin{array}{c}\text { En8 Steel Core } \\
\text { (quenched and } \\
\text { tempered) }\end{array}$ & 7.784 & $197^{\mathrm{b}}$ & 558 & $465^{[16]}$ \\
\hline $\begin{array}{c}\text { Armox Advance } \\
\text { plate }\end{array}$ & 7.783 & $219^{\mathrm{b}}$ & 677 & $1600^{[17]}$ \\
\hline $\begin{array}{c}\text { Copper Jacket (C } \\
\text { 101) }\end{array}$ & 8.924 & $123^{\mathrm{b}}$, & 71 & $70^{[19]}$ \\
\hline Aluminium 7075 & 2.806 & $117^{[18]}$ & 152 & $95^{[20]}$ \\
\hline
\end{tabular}

${ }^{a}$ Density was measured by using Density Measurement Kit (Mettler Toledo).

bYoung's modulus was determined by measuring longitudinal and shear wave velocities at $1.0 \mathrm{MHz}$ traveling within materials ${ }^{[21]}$.

'Vickers hardness number.

\subsection{Reverse-ballistic experiment}

The reverse ballistics experiments using the jacketed and unjacketed projectiles were conducted using the apparatus shown schematically in Figure 2, comprising a $50 \mathrm{~mm}$ bore single-stage gas gun 21 with an impact velocity of $750 \pm 20 \mathrm{~m} / \mathrm{s}$ that launched the steel-plate targets fixed to acetal sabots towards stationary projectiles mounted on a polycarbonate support structure. This approach eliminates the yaw associated with a small projectile in a large sabot and, importantly, ensures that impact occurs at a precise spatial point to facilitate analysis. Just before impact, a four-channel flash Xray system was initiated via a laser light gate and delay mechanism to capture radiographs at precise $10 \mu \mathrm{s}$ intervals (impact occurred nominally $30 \square \mathrm{s}$ after light gate activation). Four radiographs were produced per impact, designed to visualize the impact and determine the penetration mechanism. 


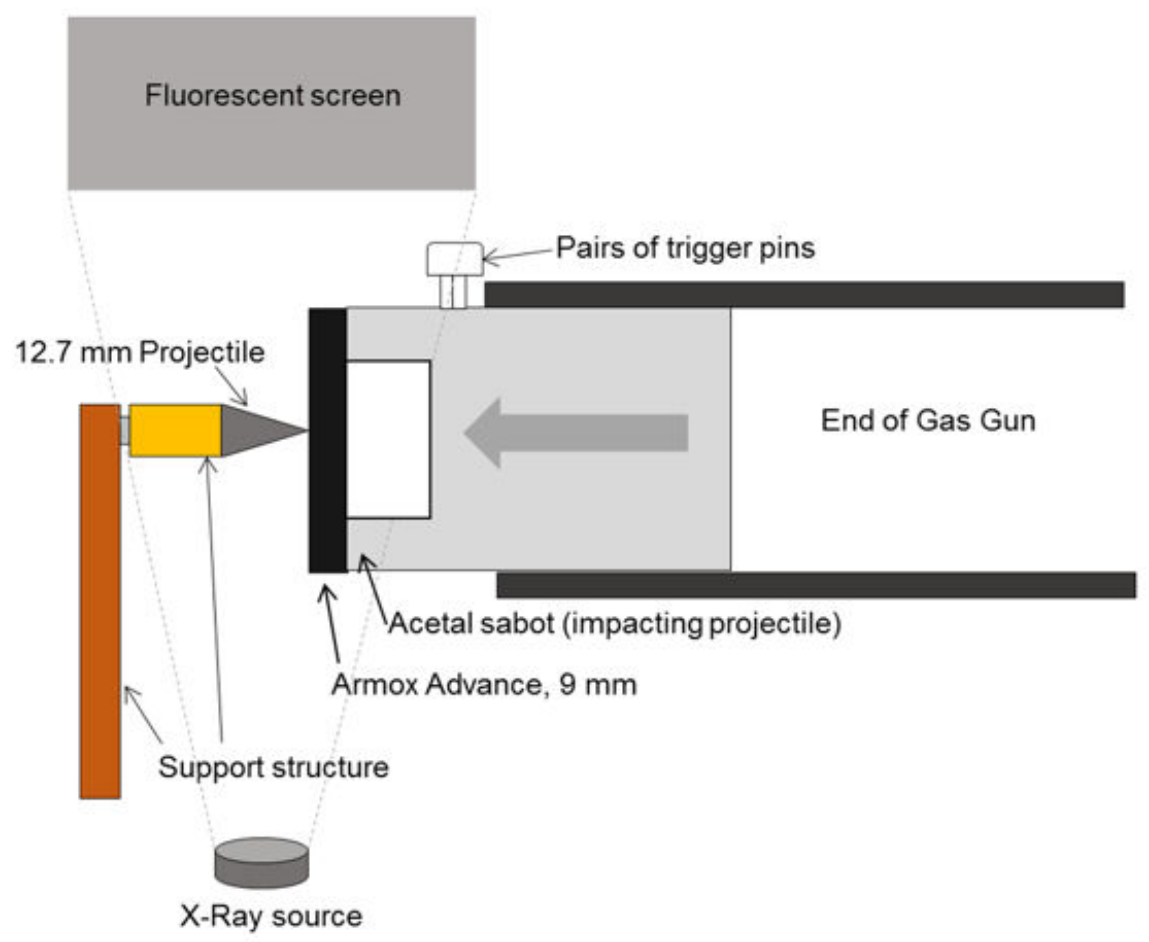

Fig. 1. Schematic illustration (not to scale) of the reverse ballistic experimental setup.

\subsection{Numerical simulation}

The impact phenomena of $12.7 \mathrm{~mm}$ projectiles subjected to the Armox Advanced target were also simulated by using an explicit non-linear dynamic finite element code LS-DYNA which is capable to investigate a complex model of large deformation. The projectiles and the targets were modeled as a constant stress solid element formulation to reduce the time-computational consuming. The core, jacket and the target were modeled using solid Lagrangian model. The projectiles were discretised in $0.35 \mathrm{~mm}$ edge element solid for the projectile body and $0.1 \mathrm{~mm}$ edge element solid for the projectile tip. The finer mesh in the tip is generated to obtain the finer failure mechanism. Figure 2 shows the smaller mesh size in the projectile tip. Target plate is meshed in $0.6 \mathrm{~mm}$ edge for the coarse element, the cental surface of is $0.2 \mathrm{~mm}$. The thickness target plate element edge is $0.5 \mathrm{~mm}$. Therefore, the total number of element for the projectile is 424016 elements, the target is 300000 elements, and the jacket is 160000 elements.

Due to the lack material properties data of Armox Advanced, Cooper and En8 steel, the strain rate effect is refered from Paik and Chung [22]. The Cowper Symonds parameters of high strength steel was used. As we concerned on the failure and penetration mechanism of the projectiles into the target, material model 3 Plastic Kinematic is used to model the isotropic and kinematic hardening 
material without the strain rate effect constant. It is considered to be very cost effective in the solid element in terms of computational time. Elastic-plastic behaviour was generated as a simple linear stress-strain graph in trapezoid graph. Elastic modulus and tangent modulus is required. Tangent modulus of the plastic behaviour is constructed by simplify the ultimate and yield strength to the plastic strain. Effective plastic strain for eroding element is required as a material failure criteria. The elongation break for each material is the input of the criteria.

The contact between the projectile and the target was modeled using eroding surface to surface. Element deletation (erosion) occurs to the involved solid element in the contact due to the material failure criteria that becomes the threshold of solid element erosion. In the figure 1, the projectile is positioned on the center of circular target. Erosion was controlled as a consequence of the contact algorithm that deleted the cells once they exceed the effective strain failure. Table 2 from the flash X-Ray become the modeling constraint of initial velocity. By simulating the same incidence velocities to the experimental testing, the simulation result will be compared. Figure shows the boundary and initial condition of simulation model. The initial velocities of $763 \mathrm{~m} / \mathrm{s}$ and $733 \mathrm{~m} / \mathrm{s}$ are applied on the target of each cases to simulate the reverse ballistic in the collide direction. The simulation is terminated after $50 \mu \mathrm{s}$. The data is captured for each $1 \mu \mathrm{s}$. Rear body is fixed at displacement to model the clamp of acetal sabot and avoid the free movement of the projectile. Four numerical simulations for each cases were simulated to investigate the damage between the projectile and the target.
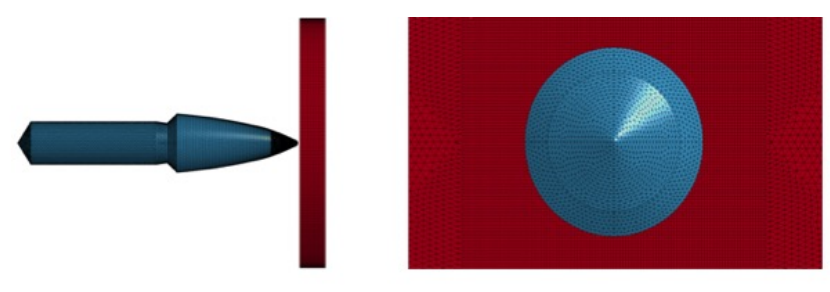

Fig. 2. Finite element model; a) Projectile and target model are meshed using LSDYNA explicit finite element code (left), b) The target square central region is meshed finer than the outer region (right).

Table 2. Key experimental data

\begin{tabular}{c|c|c|c}
\hline Exp. no. & $\begin{array}{c}\text { Thickness of } \\
\text { impactor }(\mathbf{m m})\end{array}$ & $\begin{array}{c}\text { Impact velocity } \\
(\mathbf{m} / \mathbf{s})^{\mathbf{a}}\end{array}$ & $\begin{array}{c}\text { Jacket } \\
\text { present }\end{array}$ \\
\hline 1 & 5.02 & 763 & No \\
\hline 2 & 5.01 & 763 & Yes \\
\hline 3 & 9.06 & 733 & No \\
\hline 4 & 9.06 & 733 & Yes \\
\hline
\end{tabular}




\section{Results and Discussion}

\subsection{Flash X-Ray images and numerical result}

A series of four reverse ballistic experiments was carried out using a standard core of nominally $26 \pm$ $2 \mathrm{~g}$ with and without a crimped copper jacket (adhered in line with the approach detailed previously in Section 2.1) as required. Key experimental data for these tests are presented in Table 2.

Flash X-rays for Experiments 1 and 2 (5-mm plate) are presented in Figure 4, with the time-base normalised nominally to the point of impact. Both the unjacketed and jacketed cores penetrated the 5 $\mathrm{mm}$ Armox Advance steel sheet, but the X-ray images at $10 \mu$ s reveal the different behaviours of each core during penetration. Figure $4 \mathrm{a}$ at $10 \mu \mathrm{s}$ shows that the unjacketed core started to erode at this time-point, with debris visible along the surface of the impactor. This behaviour can be attributed to the lower hardness of the core compared to the target plate. In contrast, the copper jacket appears to protect the core tip in Figure $4 \mathrm{~b}$ at $10 \mu \mathrm{s}$, allowing the jacketed core to penetrate the plate further than the unjacketed core. At $30 \mu \mathrm{s}$, it is immediately apparent that more damage has been done to the impactor plate by the jacketed core than the unjacketed core. However, both cores penetrated the $5 \mathrm{~mm}$ plate and several core and impactor fragments were produced by the impact.

Figure 4 shows cross section of the plastic strain numerical results of projectile impact on the $5 \mathrm{~mm}$ Armox Advance target. The colour contour indicate the strain value. Blue colour shows non plastic strain, it is gradually changing to the red colour as the high plastic strain. Figure $4 a$ ) reveals the unjacketed projectile and $4 \mathrm{~b}$ ) reveals the response of jacketed projectile during the impact. At $0 \mu \mathrm{s}$, the initial conditions show the projectile position right before the target impact the core. At $10 \mu \mathrm{s}$, the projectile began to penetrate the target. Some solid cells between the eroding contact area were eroded due to the effective plastic strain reach the failure criteria. At $20 \mu \mathrm{s}$, the penetration on the target was continued as the impact energy had not run out yet. In this period, both of unjacketed and jacketed specimen did not break the Armox Advance target, it was only penetrated through the target and formed a hollow with the similar width of the projectile radius section. At $30 \mu \mathrm{s}$, more damage occurred on both of projectile and target. Projectiles fully penetrated the target. It created a crack and broke the plate. The panel failed by penetration of the projectile at the center region since the target is set to head symmetrically to the projectile. Through the visual examination of numerical results, a clear difference between the jacketed and unjacketed that the core showed a shape deformation on the jacketed projectile is covered by the copper jacket. This could be because of the jacket protects the core and eroded first before the core erosion during the rapid collision. 
Comparing the result of experimental and numerical simulation, the main evident aspect that the reverse ballistic experiment results the target broken after $20 \mu \mathrm{s}$. During the impact, the target was also deformed larger than the simulation result before it was damaged and fractured. It is seen because the material model in the simulation use limited data material that the included the strain rate effect use the Cowper Symonds parameter from Paik and Jung [22]. These parameters can use to model the strain effect, however the precision of parameter number should be specified for each high strength steel material. Park and Jung [22] explained that the strain rate hardening made a material getting more brittle and tends to become more fragile. The response of material properties in the high impact velocity depends on the strain rate. Regarding the material data, the smooth stressstrain data for core, target and jacket material is not provided. A simple trapezoidal stress-strain graph is used in elastic kinematic material model.

The boundary and initial conditions of experimental and numerical model were also different. In the numerical model, the initial velocity was applied on the whole body of target part. However, in the experimental testing as seen in Figure 1 and illustrated in Figure 2, the target was mounted on the tubular sabot to push the target edge and penetrated at the center position. The edge target becomes a support when the projectile force to penetrate and break the target into fragments when the impact energy between projectile and target reaches the failure strength of Armox Advance.

Flash X-rays for Experiments 3 and 4 (9 $\mathrm{mm}$ plate) are presented in Figure 5, with the time-base again normalised nominally to the point of impact. The thicker impactor provided a clearer picture of the behaviour of the cores during impact by prolonging the interaction time and avoiding the catastrophic failure of the plate. The failure of the unjacketed core began at nominally $10 \mu \mathrm{s}$ after impact, with some radial flow of the core visible (Figure $5 \mathrm{a}$ at $10 \mu \mathrm{s}$ ). In contrast, copper jacket deformation was observed before the jacketed core contacted the plate, as shown by the conical interaction zone between the jacket and plate in Figure $5 \mathrm{~b}$ at $10 \mu \mathrm{s}$. Further contact between the impactor plate and the unjacketed core resulted in the continued failure of the core, illustrated by the flow of fragments around the point of impact in Figure $7 \mathrm{a}$ at 20 and $30 \mu \mathrm{s}$. In contrast, the jacketed core (Figure 5b) shows relatively little damage at $20 \mu \mathrm{s}$, with only copper jacket 'splash' on the plate surface. The jacketed core only begins to flow on the surface at $\sim 30 \mu \mathrm{s}$. A comparison of Figures $5 \mathrm{a}$ and $5 \mathrm{~b}$ at 30 $\mu$ clearly shows that the presence of a copper jacket leads to a much finer (both in size and dispersion) degree of eroded material moving radially away from the point of impact. This behaviour, indicative of more efficient penetration, was also evident during the penetration of the 5-mm plate (Figure 
5). The copper jacket appears to protect the core through a combination of confinement and cushioning (with the ductile copper preventing excess loading on impact) such that the shielded core remains intact for longer than the unjacketed core. The jacketed core therefore has a higher energy density on impact and penetrates further into the target.

Figure 5 shows cross section of plastic strain of numerical results of projectile impact on the $9 \mathrm{~mm}$ Armox Advance target. Figure 5 a) shows the response of the unjacketed projectile and 5 b) shows the jacketed projectile. At $0 \mu \mathrm{s}$, the initial conditions show the projectile position right before the target impact the core. At $10 \mu \mathrm{s}$, the target move ahead the static projectile and began to impact the target. Solid cells of Armox and En8 steel were eroded because the failure strain was reached. At $20 \mu \mathrm{s}$, the collision continued. More severe damage occurred at both of the target and the core. At $30 \mu \mathrm{s}$, perforation became deeper and the target push forward to the projectile. Solid cells at both were eroded more before the target stopped at the limitation boundary. At this state, the target stopped and the core could make a large damage at the Armox. Through the visual examination at the end of the simulation, the jacketed core created a more severe damage and larger cavity on the target.

These numerical results affirm the created damage of the experimental results that the protected core penetrates further and larger into the target. This could be caused as stated at the previous paragraphs that the copper jacket protects the core by confining and shielding during the impact collision. The copper jacket became plastic to absorb the earlier impact energy before the target went through the core. However, the 'splash' fragments could not be captured in the numerical because the eroding contact parameter allows the failure fragments to be deleted. The symmetrical meshing and distribution of element carry the impact loading from the projectile. Due to the eroding contact, the symmetrical failure stress reached and delete the element surrounding the projectile-target area equally. However, the testing target made of Armox Advanced steel could have a micro defect due to the material processing or handling. The other reason could be that the microstructure decide the crack propagation way. The experimental testing indicate the unsymmetrical properties spread the target area. 

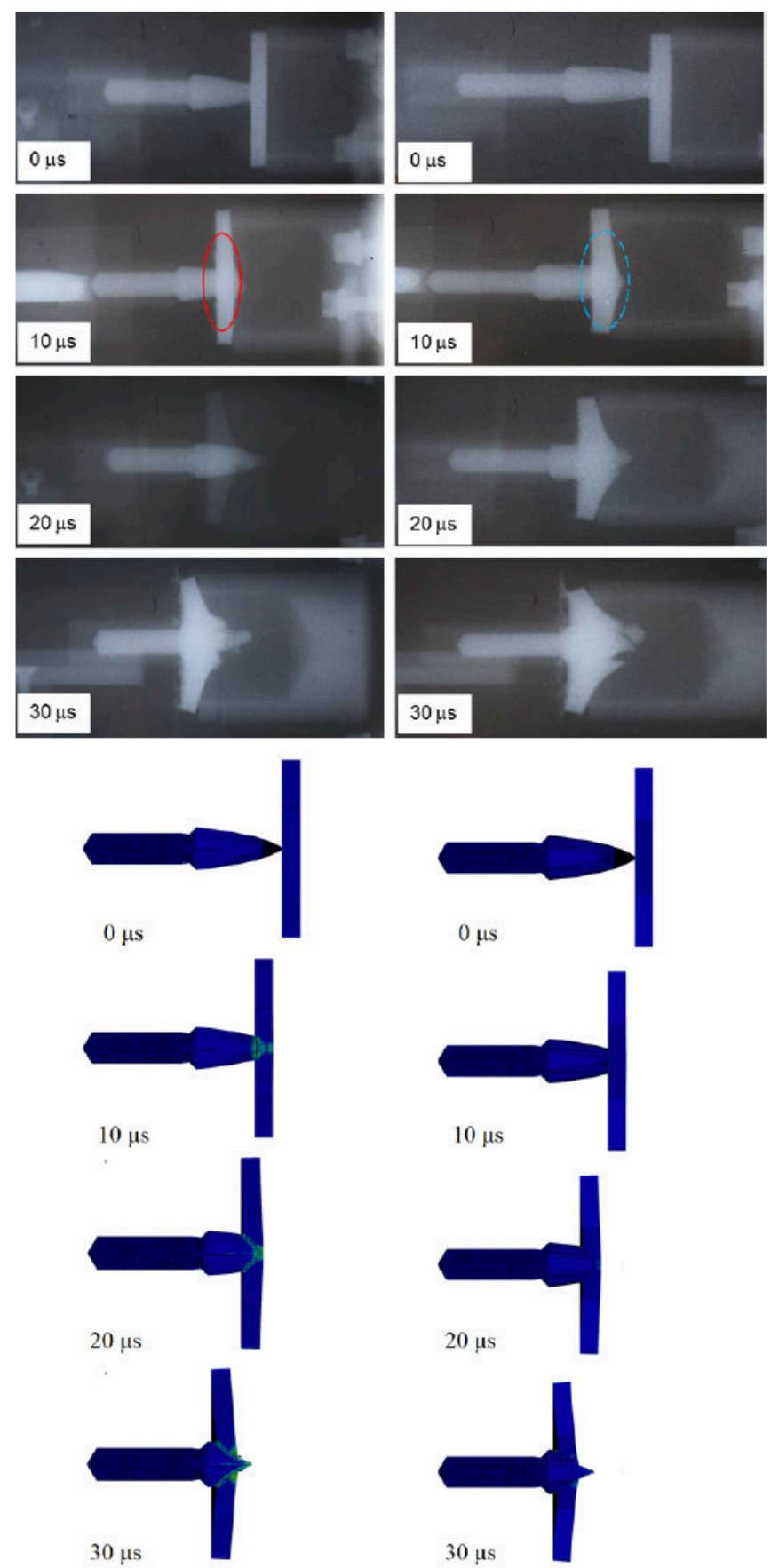

$30 \mu \mathrm{s}$

$30 \mu \mathrm{s}$

Fig. 4. Flash X-rays showing the impact of a $5 \mathrm{~mm}$ Armox Advance steel plate onto pre-positioned AP cores, top) experimental result, bottom) numerical result, left) Unjacketed core (Experiment 1 from Table 2), right) Jacketed core (Experiment 2 from Table 2). 


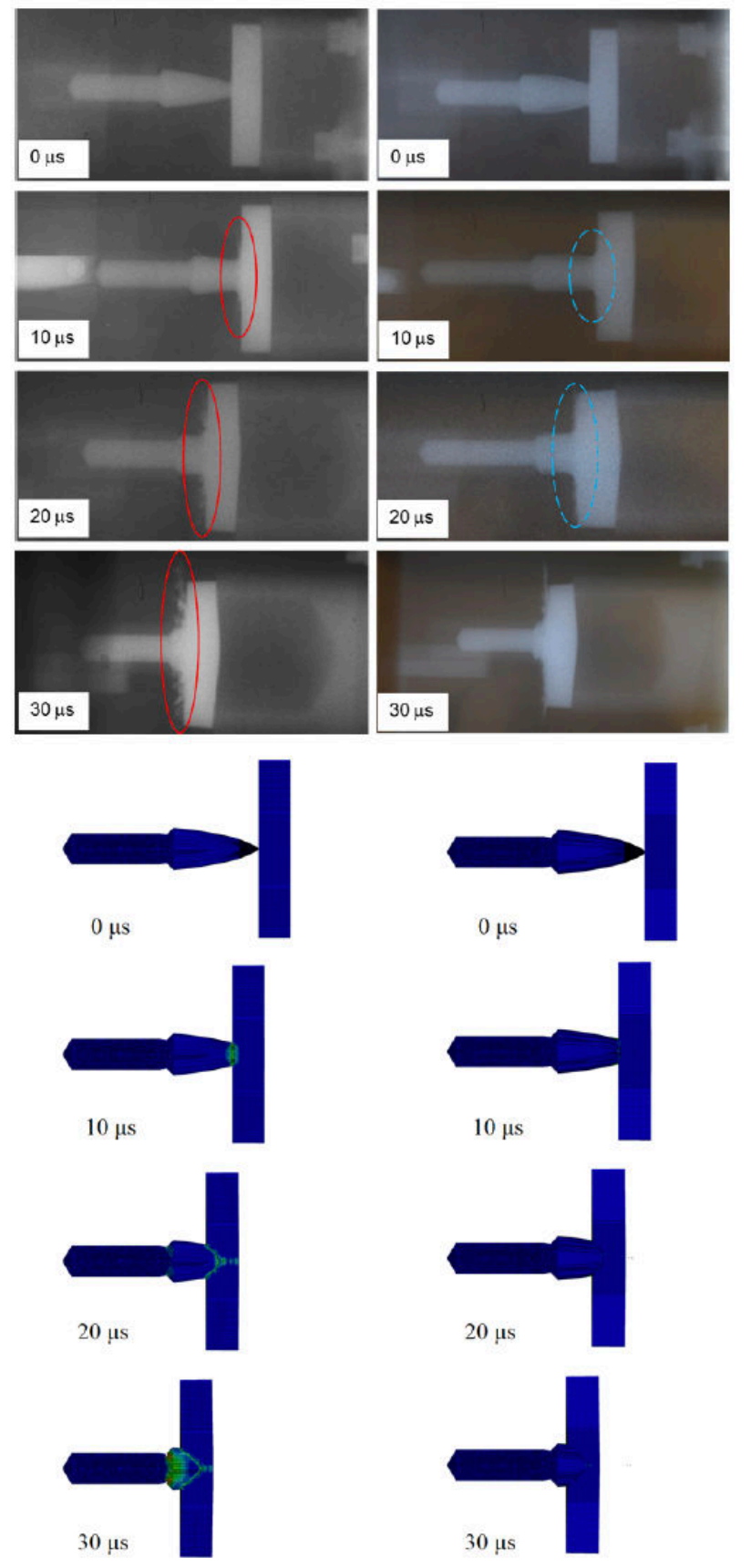

Fig.5. Flash X-rays showing the impact of a $9 \mathrm{~mm}$ Armox Advance steel plate onto pre-positioned AP cores, top) experimental result, bottom) numerical result, left) Unjacketed core (Experiment 3 from Table 2), right) Jacketed core (Experiment 4 from Table 2).

\subsection{Impactor and core recovery}

As detailed in Section 3.1., the reverse ballistics testing produced clear X-ray images of both the projectile and the impactor behaviour during penetration. To provide further insight into the effect of the copper jacket during penetration, the impactors and the associated cores were recovered for 
analysis after each experiment. Figures 10 and 11 show the core and impactor materials recovered from the experiments using the 5 and $9 \mathrm{~mm}$ thick Armox Advance steel plates, respectively. The data are summarised in Table 4. For $5 \mathrm{~mm}$ plates, the unjacketed projectile impact on the target results the reducing core length $17.74 \%$ and the reducing of jacketed projectile is $15.21 \%$. This could indicate that the presence of the jacket has an advantageous effect on the penetration of an Armox Advance target. The copper jacket absorbed the initial impact energy at the impact beginning before the core collide the target right after the copper jacket fails. The presence of the jacket protects the core from the impact damage.

Based on the numerical result, it affirms the above discussion that the penetration of the jacketed core has smaller reduction of the initial length core. The numerical results in Table 1 present that $22.15 \%$ length of unjacketed core is eroded during the penetration of $5 \mathrm{~mm}$ target, while $20.81 \%$ which is less than the latter. The differences between numerical and experimental result is less than $6 \%$. Meanwhile, a larger difference occurs at the $9 \mathrm{~mm}$ result. The numerical jacketed results shows a longer residual core, the reduction is only $37.31 \%$, while the testing results $47.64 \%$. The unjacketed shows underestimated reduction as well. The eroding elements are only $45.87 \%$, while the testing shows $50.03 \%$ of the core length are reduced. This could be occurs due to the simple material model and limited material data used. Elastic plastic

Therefore, these simulations clearly shows that damage occurs to the copper jacket prior to contact by the core. The initial energy of the impact has been reduced by the damaging of jacket before the target move through the core. Consequently, the using of copper jacket leads to a less damage to the core.

The impact testing of $5 \mathrm{~mm}$ plates also resulted the targets on some fragments. For the unjacketed projectile, the target broke into 7 fragments. For the jacketed projectile, the target broke into more pieces as 10 fragments. The numerical simulations show different results. Compared to the experimental that broken into pieces, numerical models show targets that were only penetrated in the hollow of the projectile radius without breaking for all cases. It could happened because the Armox Advance is only modelled as a material model without strain rate effect as stated in the above discussion.

The presence of a jacket reduced the amount of projectile erosion during impact with both target plates, thus enhancing penetration. Unsurprisingly, erosion was more severe with the thicker plate, but the jacket appeared to reduce core erosion during impact with both targets. This suggests that 
the jacket may provide a quantitative degree of protection and enhanced penetration regardless of the nature of the target by reducing the amount of core erosion experienced on impact. These data are consistent with the captured flash X-ray images shown in Figures 4 and 5.

Table 3. Steel core (initial length $55.31 \mathrm{~mm}$ ) and impactor recovery after impact result by experimental (Exp.) and finite element method (FEM)

\begin{tabular}{|c|c|c|c|c|c|c|c|}
\hline $\begin{array}{l}\text { Exp. no. } \\
\text { (see Table } \\
\text { 2) }\end{array}$ & $\begin{array}{l}\text { Thicknes } \\
\text { s } \\
\text { of impac } \\
\text { tor ( } \mathrm{mm})\end{array}$ & $\begin{array}{l}\text { Jack } \\
\text { et pr } \\
\text { esent }\end{array}$ & $\begin{array}{l}\text { No. of impa } \\
\text { ctor } \\
\text { fragments } \\
(>0.8 \mathrm{~g})\end{array}$ & $\begin{array}{l}\text { Remaining } \\
\text { core lengt } \\
\quad h, \\
\text { Exp. }(\mathrm{mm})\end{array}$ & $\begin{array}{l}\text { Reduction } \\
\text { in } \\
\text { core lengt } \\
h \text {, } \\
\text { Exp. (\%) }\end{array}$ & $\begin{array}{l}\text { Remaining } \\
\text { core lengt } \\
\qquad \mathrm{h} \text {, } \\
\text { FEM (mm) }\end{array}$ & $\begin{array}{l}\text { Reduction } \\
\text { in } \\
\text { core lengt } \\
h \text {, } \\
\text { FEM (\%) }\end{array}$ \\
\hline 1 & 5.02 & No & 7 & 45.50 & 17.74 & 43.06 & 22.15 \\
\hline 2 & 5.01 & Yes & 10 & 46.90 & 15.21 & 43.80 & 20.81 \\
\hline 3 & 9.06 & No & - intact - & 27.64 & 50.03 & 29.94 & 45.87 \\
\hline 4 & 9.06 & Yes & - intact - & 28.96 & 47.64 & 37.44 & 37.31 \\
\hline
\end{tabular}

\section{Conclusions}

In this work, a series of four reverse ballistics experiment were carried out to determine the influence of a copper jacket on the penetration of a bespoke hardened steel AP round in steel armour plates. Four numerical simulations were also executed to be compared with the experimental result. The analysis of flash X-ray images and material recovered post-shot resulted in the following key findings:

1. The presence of a copper jacket appears to protect En8 steel cores by absorbing the impact energy reflected during the impact in high strain rate condition and mitigating its subsequent propagation into the steel core.

2. Confinement and cushioning of the core appears to be important, evidenced by the finer nature (size and distribution) of eroded material spreading across the target surface when a jacket is present. This finding validates the observation made in the studies previously reported by various authors.

3. Analysis of recovered core lengths (e.g. a direct measure of the extent of projectile erosion) not only backed analysis of the captured flash X-rays and pressure gauge experiments, but also provided tentative evidence of a quantifiable contribution of the presence of a jacket to enhanced core protection. In particular, the difference of core length reduction (jacketed versus unjacketed) was $2.53 \%$ and $2.39 \%$ for 5 and $9 \mathrm{~mm}$ thick Armox Advance plate experiments 
and approximately $3 \%$ and $8 \%$ for the numerical simulations, suggestive of a consistent mechanism controlling.

4. The numerical simulation of $5 \mathrm{~mm}$ target impact match with the corresponding experiments that the remaining core length has relatively similar. However, the target failure modes show different behaviour (no projectile fragmentation). The numerical simulation only shows a penetration process during the impact without any plate fracture. Numerical simulations of $9 \mathrm{~mm}$ target impact also show different result that the projectile success to penetrate the armour.

5. The numerical simulations affirms the experimental results that the presence of copper jacket results in a less damage of core length reduction by protecting the core prior to the cells erosion of the jacket during the high impact event.

\section{Acknowledgments}

The authors would like to thank Karl Norris, Adrian Mustey, David Wood and Andrew Roberts for help in preparing the targets and supporting the ballistic testing in of the Dynamic Response Group at Cranfield University's Shrivenham Campus. The authors also acknowledge the Indonesia Endowment Fund for Education (LPDP) which supported both the experiments and the MSc by Research programme. Thanks are due to LSTC for providing academic license on LS-DYNA computational software.

\section{References}

[1] Feng J, Sun W, Liu Z, et al. An armour-piercing projectile penetration in a double-layered target of ultrahigh-performance fiber reinforced concrete and armour steel: Experimental and numerical analyses. Mater Des 2016; 102: 131-141.

[2] Atapek SH. Development of a new armor steel and its ballistic performance. Def Sci J 2013; 63: 271-277.

[3] Worsham MJ, Treadway SK, Shirley AD. Defeat of high velocity projectiles by a novel spaced armor system. Procedia Eng 2013; 58: 338-347.

[4] Liu W, Chen Z, Cheng X, et al. Design and ballistic penetration of the ceramic composite armor. Compos Part B Eng 2016; 84: 33-40.

[5] Crouch IG, Appleby-Thomas G, Hazell PJ. A study of the penetration behaviour of mild-steel-cored ammunition against boron carbide ceramic armours. Int J Impact Eng 2015; 80: 203-211.

[6] Li QM, Flores-Johnson EA. Hard projectile penetration and trajectory stability. Int J Impact Eng 2011; 38: 815-823.

[7] Hazell PJ, Appleby-Thomas GJ, Philbey D, et al. The effect of gilding jacket material on the penetration mechanics of a $7.62 \mathrm{~mm}$ armour-piercing projectile. Int J Impact Eng 2013; 54: 1.

[8] Kiliç N, Ekici B. Ballistic resistance of high hardness armor steels against $7.62 \mathrm{~mm}$ armor piercing ammunition. Mater Des 2013; 44: 35-48. 
[9] Forrestal MJ, B??rvik T, Warren TL. Perforation of 7075-T651 Aluminum Armor Plates with $7.62 \mathrm{~mm}$ APM2 Bullets. Exp Mech 2010; 50: 1245-1251.

[10]Forrestal MJ, Warren TL, Børvik T, et al. Perforation of 6082-T651 Aluminum Plates with 7.62 mm APM2 Bullets at Normal and Oblique Impacts. Conf Proc Soc Exp Mech Ser 2015; 65: 389-402.

[11]Brown LB, Hazell PJ, Crouch IG, et al. Computational and Split-Hopkinson Pressure-Bar studies on the effect of the jacket during penetration of an AK47 bullet into ceramic armour. Mater Des 2017; 119: 47-53.

[12]Kiliç N, Bedir S, Erdik A, et al. Ballistic behavior of high hardness perforated armor plates against $7.62 \mathrm{~mm}$ armor piercing projectile. Mater Des 2014; 63: 427-438.

[13]Showalter DD, Gooch WA, Burkins MS, et al. Development and Ballistic Testing of a New Class of High Hardness Armour Steel. 2008; 4: 7-10.

[14]Diederen a M, Broos JPF, Trigt SN Van. Ballistic Protection Against Armour Piercing Projectiles Using Titanium Base Armour. Cost Eff Appl Titan Alloy Mil Platforms 2001; 99: 7-11.

[15]Ryan S, Li H, Edgerton M, et al. The ballistic performance of an ultra-high hardness armour steel: An experimental investigation. Int J Impact Eng 2016; 94: 60-73.

[16]OTAI Special Steel. EN8 Carbon Steel, 080M40 BS 970 Specification, http://www.astmsteel.com/product/en8-carbon-steel-080m40-bs-970/ (Accessed: 15 September 2017).

[17]Showater DD, Gooch WA, Burkins MS, et al. Ballistic Testing of SSAB Ultra-High-Hardness Steel for Armor Applications, http://www.armorindustry.com/images/stories/ ADA493654..pdf (2008, accessed 19 October 2017)

[18]Smith Metal. C101 Technical Data Sheet - Copper, https://www.smithmetal.com/pdf/copper-brassbronze/copper/c101.pdf (2017, accessed: 11 October 2017)

[19]Engineer Edge. Yield Strength - Strength (Mechanics) of Materials, https://www.engineersedge.com/material_science/yield_strength.htm (accessed: 11 October 2017)

[20]AZO Materials. Aluminum 7075 Alloy (UNS A97075), https://www.azom.com/article.aspx?ArticlelD=6652 (accessed: 13 November 2017)

[21]Proteq. Determination of Poisson's Ration and the Modulus of Elasticity by measuring with P- and S-wave transducers, https://www.proceq.com/uploads/tx_proceqproductcms/import_data/files/Determining\%20Poissons\%20ratio\%20and\%20Elastic\%20modulus.pdf (2017, accessed: 19 October 2017)

[22]Paik JK, Chung JY. A basic study on static and dynamic crushing behavior of a stiffened tube. Transactions, The Korean Society of Automotive Engineers (KSAE) 1999;7(1):219-238. 